\title{
Development of Digital Portable Auto Design Microscope Learning Media to Increase the Understanding of Concepts and Problem-Solving Abilities of Students
}

\author{
Aris Doyan ${ }^{1,2^{*}}$, Susilawati ${ }^{1,2}$, Adi Hardiyansyah ${ }^{1}$ \\ ${ }^{1}$ Master of Science Education Program, University of Mataram, Lombok, West Nusa Tenggara, Indonesia \\ ${ }^{2}$ Physics Education, FKIP, University of Mataram, Lombok, West Nusa Tenggara, Indonesia \\ ${ }^{*}$ Corresponding author. Email: aris_doyan@unram.ac.id
}

\begin{abstract}
The purpose of this research is to develop learning media in the form of portable digital auto microscope design to improve understanding of concepts and problem-solving abilities. The results showed that the learning media in the form of portable digital microscope auto design is very feasible to use in learning. This can be seen from the results of expert validation $97.78 \%$. After getting the results of validation then the effectiveness of this media is tested on the understanding of concepts and problem-solving abilities. The results of the effectiveness test showed that this media was very effective in increasing the understanding of the concepts and abilities of students in two schools namely SMP IT Putra and SMP IT Putri Mataram. The effectiveness test results show that there is an increase in the score of students in pre-test and post-test.
\end{abstract}

Keywords: Digital portable, Auto Design Microscope, Understanding of Concepts, Problem-solving abilities.

\section{INTRODUCTION}

The implementation of education in Indonesia refers to the national education system contained in Law Number 20 Year 2003 concerning the National Education System, Article 1 number 1 states that education is a conscious and planned effort to create an atmosphere of learning and learning process so that students actively develop potential himself to have spiritual strength, selfcontrol, personality, intelligence, noble character, and the skills needed for himself, society, nation and state [1]. The development of education is inseparable from the important efforts to form a qualified young generation by increasing the quality of education. Good education is education with the availability of qualified educators in terms of planning and implementing learning and evaluating learning outcomes [2].
The development of education in the world is also inseparable from the development of the industrial revolution that occurred in the world, because indirectly changes in the economic order also change the educational order in a country. The industrial revolution began with the Industrial Revolution 1.0 occurring in the 18th century through the invention of the steam engine, allowing for mass production of goods. Around 1970 through the use of computerization, and the 4.0 Industrial Revolution itself occurred in around 2010 through intelligence engineering and the internet of things as the backbone of the movement and connectivity of humans and machines [3].

Facing the Era of the Industrial Revolution 4.0 in the field of education, motivation alone is not enough in realizing the ideals of making Indonesia 4.0, there must be concrete form and hard work for the Indonesian 
government and all of us in welcoming the era of digitalization [4]. One concrete effort to deal with this era is to improve the quality of education [5]

Education in Indonesia is still relatively low and has not yet succeeded optimally, even more so for learning science. The main problem in education in Indonesia is the low learning outcomes in schools. Learning outcomes are meant not only in the aspect of cognitive abilities but also in aspects of attitude or attitude towards science [6].

Survey results at the Integrated Islamic Junior High School Putra and Putri Mataram (SMP IT Mataram) that many of them do not like even afraid of some lessons, especially science and mathematics lessons [7]. This is due to several factors, among which are the media and scenarios that are less innovative in the learning process, which means that the teaching and learning process that is held is generally based on material (content based) [8]. In the learning process, students are less encouraged to develop thinking skills. The learning process in the classroom is directed at the child's ability to memorize information. Children's minds are forced to understand the information they remember to connect it with everyday life [9].

The development of science and technology has brought very significant changes to various dimensions of human life, both in terms of economics, socio-culture, and education. Rapid changes in all sectors of life must be a driving force for schools and colleges to be able to adapt and innovate in order to keep up with changes and developments very quickly in the global arena [10]. Mobile lately known as smartphones or gadgets can be a supporting medium for the creation of creative learning. Utilization of a smartphone equipped with a camera that produces high Image Quality will be a medium that will facilitate learning activities.

The existence of this gadget with various features in it can provide convenience in teaching various science learning materials in schools. One of them is light material and optical devices, the existence of this gadget will be a supporter of learning activities, given the availability of instructional media that is still very minimal, such as a microscope. Microscopes available in schools now have many drawbacks, some of which can only work well if used in a luminous room. So, it takes innovation to design a portable digital auto design microscope that can be used in a variety of circumstances.

Talking about global challenges, of course many bills and homework must be met by students. Among them is the ability to understand a material concept and the ability to solve problems [11]. In science there is a request to process ways of thinking, conducting investigations, building knowledge and its relation to technology and society. This becomes a basic supplement in studying science to develop scientific processes so that students' mindset is formed [12].

Science learning activities must involve students in their investigations and be able to integrate skills, attitudes, and knowledge to understand the science concepts [13]. Science learning activities emphasize direct learning to develop students' competencies in exploring and understanding nature scientifically [14]. Furthermore, the purpose of science education is to create students who master the concepts and their relationships to solve problems in everyday life [15].

The importance of problem-solving skills is in line with the opinion issued by the National Council of Teachers of Mathematics (NCTM) in 2000 which states that the problem-solving ability must be possessed by every student to support the quality of human resources. Students who are trained to have the ability to solve problems will be able to compete globally because they are able to integrate these abilities to solve real problems in the real world [16].

This skill is one of the intellectual properties or the ability to produce or produce products. Therefore, a development research entitled "development of portable auto design digital microscope learning media to remind students of the concept understanding and problemsolving ability of junior high school students on light material and optical devices".

\section{METHOD}

This research is a research and development that uses the Dick and Carey development model. The Dick and Carey development model has ten stages of development: (1) Formulating Specific Learning Objectives; (2) Student and Context Analysis; (3) Instructional Analysis; (4) Identification of Learning Objectives; (5) Developing Tools or Instruments; (6) Developing Learning Strategies; (7) The use of teaching materials; (8) Designing and carrying out formative evaluations; (9) Revise the draft learning program; (10) Designing and developing summative evaluations [17].

The product developed is a portable auto design digital microscope learning media to improve understanding of concepts and problem-solving abilities of students of grade VIII junior high school in light material and optical devices. The data used are data obtained from the results of the validation of the media experts, then analysed using component percentages based on the Likert scale in Table 1.

Table 1. Scoring instrument questionnaire

\begin{tabular}{|l|c|}
\hline Answer & Score \\
\hline Very good & 5 \\
\hline Good & 4 \\
\hline Enough & 3 \\
\hline Minus & 2 \\
\hline Very Poor & 1 \\
\hline
\end{tabular}


Then the score is calculated to determine the percentage of components with the following equation:

$$
P_{(k)}=\frac{S}{N} \times 100 \%
$$

Where:

$P_{(k)}=$ Percentage of components

$S=$ Total component score of research results

$N=$ Maximum number of scores

The percentages obtained are then transformed into intervals as in Table 2 .

Table 2. Range of percentages and qualitative criteria

\begin{tabular}{|c|l|}
\hline Percentage (\%) & Criteria \\
\hline $85-100$ & Very Worthy \\
\hline $69-84$ & Feasible \\
\hline $53-68$ & Enough \\
\hline $37-52$ & Inadequate \\
\hline $20-36$ & Very Poor \\
\hline
\end{tabular}

The effectiveness of the product developed can be seen from tests of concept understanding and problemsolving abilities. The results obtained in the form of pretest and posttest values, which are then calculated the value of $\mathrm{N}$-Gain to see an increase in the achievement of the concept understanding and problem-solving ability. To see the improvement of students' creativity and problem-solving ability, the N-Gain formula is used as follows:

$$
\mathrm{N}-\text { Gain }=\frac{\text { Spost }- \text { Spre }}{\text { Smax }- \text { Spre }} \times 100 \%
$$

The table of N-Gain score criteria can be seen in the following Table 3:

Tabel 3. Gain score criteria [18]

Gain score classification. Category

\begin{tabular}{l|l}
$0.7<g \leq 1$ & Height \\
\hline
\end{tabular}

\begin{tabular}{l|l}
$0.7<g \leq 0.7$ & Medium
\end{tabular}

\begin{tabular}{l|l}
$\boldsymbol{g} \leq 0.3$ & Low
\end{tabular}

\section{RESULT AND DISCUSSION}

\subsection{Validation Results of Learning Media Digital Portable Auto Microscope Design}

The media validation developed was carried out by three media and material expert validators. Validation is based on 3 main components, namely general appearance, special appearance, and media presentation. In general, comments from the validator are that there needs to be a change in the colour of the microscope, the microscope box, the light holes, the number of lenses from 1 lens to 2 lenses, and the rotator to adjust the focus. The results of the final validation from the validator can be seen in Table 4 below:
Table 4. Recording of portable auto design microscope validation results

\begin{tabular}{|l|l|}
\hline Assessment Aspect & Score (\%) \\
\hline General Display & 98.09 \\
\hline Custom Views & 97.78 \\
\hline Presentation of Media & 97.33 \\
\hline Average & 97.78 \\
\hline Criteria & Very Eligible \\
\hline
\end{tabular}

Table 4. shows that the average result of the validation of learning media in the form of a portable auto design microscope is $97.78 \%$ with very feasible criteria. This shows that this learning media is suitable for use in learning. The following is an image of the portable auto design microscope learning media that has been developed (Figure 1a) and an example of the resulting Ant image (Figure 1b).

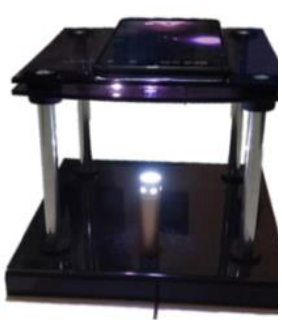

(a)

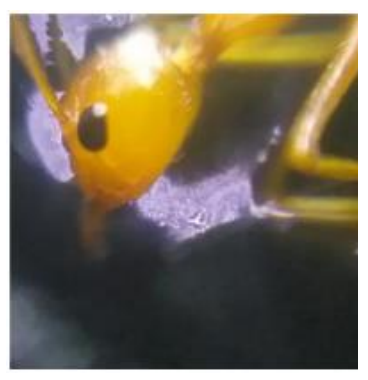

(b)
Figure 1 (a) Digital microscope portable auto design developed, (b) Ant image.

The picture above is a portable auto design digital microscope image that was developed as a science learning medium on Light material and Optical Devices in class VIII. This media is a simple media designed using a laser lens. This digital microscope has the same function as light microscopy in general, which is to see objects or small objects. The fundamental difference with a light microscope is that this microscope uses a smartphone application to see the anatomy of the object being observed, so its use is simple, and can be displayed on an LCD screen. Another advantage is that the object being observed can be taken pictures or videos, so that students can easily study the anatomy of the observed animals and plants because they can be seen repeatedly.

\subsection{The results of the effectiveness test of the Portable Auto Design Digital Microscope learning media}

To see the effectiveness of the media and tools developed, it was carried out through tests of students' abilities on the variables to be measured, namely understanding of concepts and problem-solving abilities. The results of the concept mastery test can be seen in Figure 2 below. 


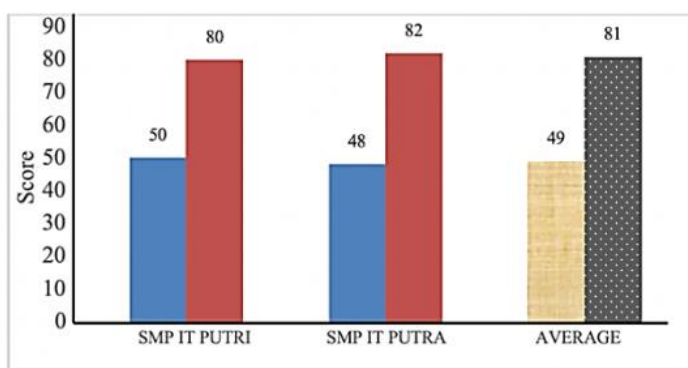

Figure 2 Value of the pretest and posttest mastery of the concept.

The picture above is the result of the pretest and posttest in two schools, namely SMP IT Putra and SMP IT Putri Mataram. The graph shows that there is a significant difference between the pretest and posttest scores. This shows that the learning media developed are effective in increasing students 'understanding of concepts and at the same time being able to attract students' interest.

Interest is the first capital to form learning motivation. Students who have an interest in learning will definitely be sincere so that they can achieve achievements [19]. Likewise, on the contrary, students who do not have a request to learn tend not to pay attention to the lesson [20].

The results showed that the learning motivation of students had an effect of $48 \%$ on the learning achievement of students [21]. The results also show that students who have higher learning motivation will find it easier to follow the learning process [22]. Conversely, students with low learning motivation have difficulty understanding the concept and cause a learning process that is less conducive. The results also show that to overcome this, a fun learning process is needed and students can be actively involved in the learning process [23].

This has influenced student learning outcomes to increase because learning is presented using modern media so that students' interest in learning and curiosity are high. The results of the problem-solving ability test can be seen in Figure 3 below.

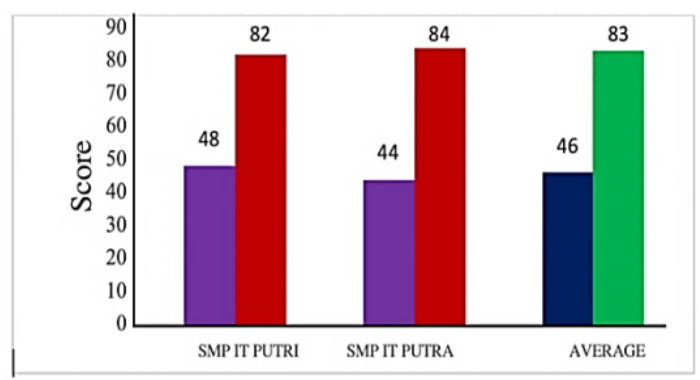

Figure 3 The value of pre-test and post-test of problemsolving abilities.
Figure 3 above shows the average pre-test and posttest scores tested at the schools that were the research subjects, namely SMP IT Putra and SMP IT Putri Mataram. This graph shows that there is a very significant increase between the pre-test and post-test scores. This shows that the portable auto design digital microscope is effective for improving the problemsolving abilities of students in schools that are the research subjects.

Students who are taught using instructional media tend to have good problem-solving skills $[24,25]$. This is because the use of instructional media is able to attract students' learning interest so they are focused and have high curiosity. There is a significant difference between students who learn to use learning media and do not use learning media $[26,27,28]$. This is because students are facilitated by the media making it easier to understand the material and tend to be able to improve problem solving well.

\section{CONCLUSION}

The portable auto design digital microscope learning media developed is very suitable for use based on the validation results. The portable auto design digital microscope learning media developed effectively improves students' understanding of concepts and problem-solving abilities. This can be seen from the difference in the results of the pree-test and post-test.

\section{AUTHORS' CONTRIBUTIONS}

Aris Doyan has contributed to making articles and data analysis. Susilawati contributed to the data analysis. Adi Hardiyansyah has contributed to data collection and data processing for making complete articles.

\section{ACKNOWLEDGMENTS}

We would like to thank the Indonesian Ministry of Research and Higher Education who has provided funding for the Master's Thesis Research. We would also like to thank the SMP IT Putra and SMP IT Putri Mataram who has given us support in doing this research.

\section{REFERENCES}

[1] Permendikbud No. 22 Tahun 2016 tentang Standar Proses Untuk Satuan Pendidikan Dasar dan Menengah

[2] Sugihartono, 2013. Psikologi Pendidikan Yogyakarta: UNY Press

[3] Prasetyo, B., \& Trisyanti, U. 2018. Revolusi Industri 4.0 Dan Tantangan Perubahan Sosial. In Prosiding SEMATEKSOS 3 "Strategi Pembangunan Nasional Menghadapi Revolusi Industri 4.0." 
[4] Subekt, H., Taufiq, M., Susilo, H., Ibrohim, I., Suwodo, H. 2018. Mengembangkan Literasi Informasi Melalui Belajar Berbasis Kehidupan Terintegrasi Stem Untuk Menyiapkan Calon Guru Sains Dalam Menghadapi Era Revolusi Industri 4.0: Review Literatur. Education and Human Development Journal, 3(1)

[5] Ibda, Hamidulloh. 2018. Penguatan Literasi Baru Pada Guru Madrasah Ibtidaiyah Dalam Menjawab Tantangan Era Revolusi Industri 4.0. JRTIE: Journal of Research and Thought of Islamic Education, Vol. 1, No. 1

[6] Rohwati, M. 2012. Penggunaan Education Game untuk Meningkatkan Hasil Belajar IPA Biologi Konsep Klasifikasi Makhluk Hidup. Jurnal Pendidikan IPA Indonesia JPII 1(1) 75-81

[7] Lee, M. K. dan I. Erdogan. 2007. The Effect of Science Technology Society on Students' Attitudes Toward Science and Certain Aspects of Creativity. International Journal of Science Education

[8] Nurhaeni, Y. 2011. Meningkatkan Pemahaman Siswa pada Konsep Listrik Melalui Pembelajaran Kooperatif Tipe Jigsaw Pada Siswa Kelas IX SMPN 43 Bandung. Jurnal Penelitian Pendidikan, 12(1)

[9] Lie. 2002. Cooperative Learning: Mempraktikkan Cooperative Learning di Ruang-Ruang Kelas. Jakarta: Gramedia Widiasarana Indonesia

[10] Sitompul, H. dan Astuti, R. 2012. Pengaruh Media Pembelajaran dan Kecerdasan Ganda Terhadap Hasil Belajar Teknologi Informasi dan Komputer (TIK) Mahasiswa PGSD Universitas Negeri Medan. Jurnal Teknologi Pendidikan, Vol. 5 No. 2

[11] Shaw, Rajib, Oikawa, dan Yukihiko. 2014. Education for Sustainable Development and Disaster Risk Reduction. Springer: Japan

[12] Aryani, Pramita, S., Akhlis, Isa., dan Subali, Bambang. 2013. Penerapan Model Pembelajaran Inkuiri Terbimbing Berbentuk Augmented Reality pada Peserta Didik untuk Meningkatkan Minat dan Pemahaman Konsep IPA. Unnes Physics Education Journal Terakreditasi SINTA 3 UPEJ 8(2)

[13] Khan, M. S., Muzaffar., \& Iqbal, M. Z. 2011. Effect of Inquiry Method on Achievement of Students in Chemistry At Secondary Level. International Journal of Academic Research, 3(1): 955-960

[14] Jannati, Edelweis, D. 2013. Model Pembelajaran Eksperimental Kolb untuk Meningkatkan Pemahaman Konsep dan Kemampuan Menjelaskan Fenomena Fisis Fisika Siswa Kelas X pada Konsep Alat Optik. Skripsi. Bandung: Universitas Pendidikan Indonesia
[15] Purwantoko, R. A. 2010. Keefektifan Pembelajaran dengan Menggunakan Media Puzzle terhadap Pemahaman IPA Pokok Bahasan Kalor pada Siswa SMP. Jurnal Pendidikan Fisika Indonesia, 6: 123

[16] Hertiavi, M. A., Langlang, H., dan Khanafiyah, S. 2010. Penerapan Model Pembelajaran Kooperatif Tipe Jigsaw Untuk Peningkatan Kemampuan Pemecahan Masalah Siswa SMP. Jurnal Pendidikan Fisika Indonesia 6 53-57

[17] Sugiyono. 2017. Statistika untuk Penelitian. Bandung: Alfabeta

[18] Arikunto, S. 2013. Prosedur Penelitian, Suatu Pendekatan Praktik Edisi Refisi VI. Jakarta: Rineka Cipta

[19] Puspitorini, R., Prodjosantoso, A.K., \& Subali, B. 2014. Penggunaan Media Komik Dalam Pembelajaran IPA Untuk Meningkatkan Motivasi Dan Hasil Belajar Kognitif Dan Afektif. Jurnal Cakrawala Pendidikan, 3(3): 413-420

[20] Akhlis, A. 2009. Keefektifan Pembelajaran Berbantuan Multimedia Menggunakan Metode Inkuiri Terbimbing Untuk Meningkatkan Minat Dan Pemahaman Siswa. Jurnal Pendidikan Fisika Indonesia, 6: 58-62

[21] Hamdu, G. \& Lisa, A. 2011. Pengaruh Motivasi Belajar Siswa terhadap Prestasi Belajar IPA di Sekolah Dasar. Jurnal Penelitian Pendidikan, 12(1): 81-86

[22] Pramadi, I. P. W. Y., Suastra, I.W., \& Candiasa, I.M. 2013. Pengaruh penggunaan komik berorientasi kearifan lokal bali terhadap motivasi belajar dan pemahaman konsep fisika. E-Journal Program Pascasarjana Universitas Pendidikan Ganesha, 3

[23] Amalia, S., Rusilowati, A., \& Supriyadi. 2011. Penerapan Physics Communication Games dengan Pendekatan SETS untuk meningkatkan Pemahaman Kebencanaan dan Minat Belajar Sains Fisika Siswa SMP. Jurnal Pendidikan Fisika Indonesia, 7:101105

[24] Haryanto, Urip. 2016. Peningkatan Kemampuan Memecahkan Masalah Melalui Media Komputer Dalam Pembelajaran Matematika Pada Siswa SMKN 1 Ngawen. Media Neliti Publication

[25] Doyan, A., Jufri, A. W., Susilawati, Hardiyansyah, A., Auliya, K.., Hakim, S., and Muliyadi, L. 2020. Development of Learning Media of Microscope Portable Auto Design to Increase Student's Problem-Solving Ability in Light and Optical Tools Topic. Atlantis Press: Advances in Social Science, Education and Humanities Research, volume 438: 300-302 
[26] Ambarwati, Marisa. 2019. Efektivitas Media Pembelajaran Berbasis Web Game Untuk Meningkatkan Kemampuan Pemecahan Masalah Pada Pembelajaran Matematika SD. Mimbar PGSD Undiksha Vol: 7 No: 2

[27] Rohwati, M. 2012. Penggunaan Education Game untuk Meningkatkan Hasil Belajar IPA Biologi Konsep Klasifikasi Makhluk Hidup. Jurnal Pendidikan IPA Indonesia JPII 1(1) 75-81

[28] Sugianto, S., Fitriani, A., Anggraeni, S., and Setiawan W. 2019. Media needs of plant anatomy practicum on digital microscope blended learning system on student naturalist intelligence. Journal of Physics: Conference Series 1280 (2019) 032010.

DOI: $10.1088 / 1742-6596 / 1280 / 3 / 032010$ 